\title{
Pola Asuh Anak Cerdas Istimewa dalam Islam
}

\author{
Hery Setiyatna, Putri Melati
}

IAIN Surakarta, Surakarta, Indonesia

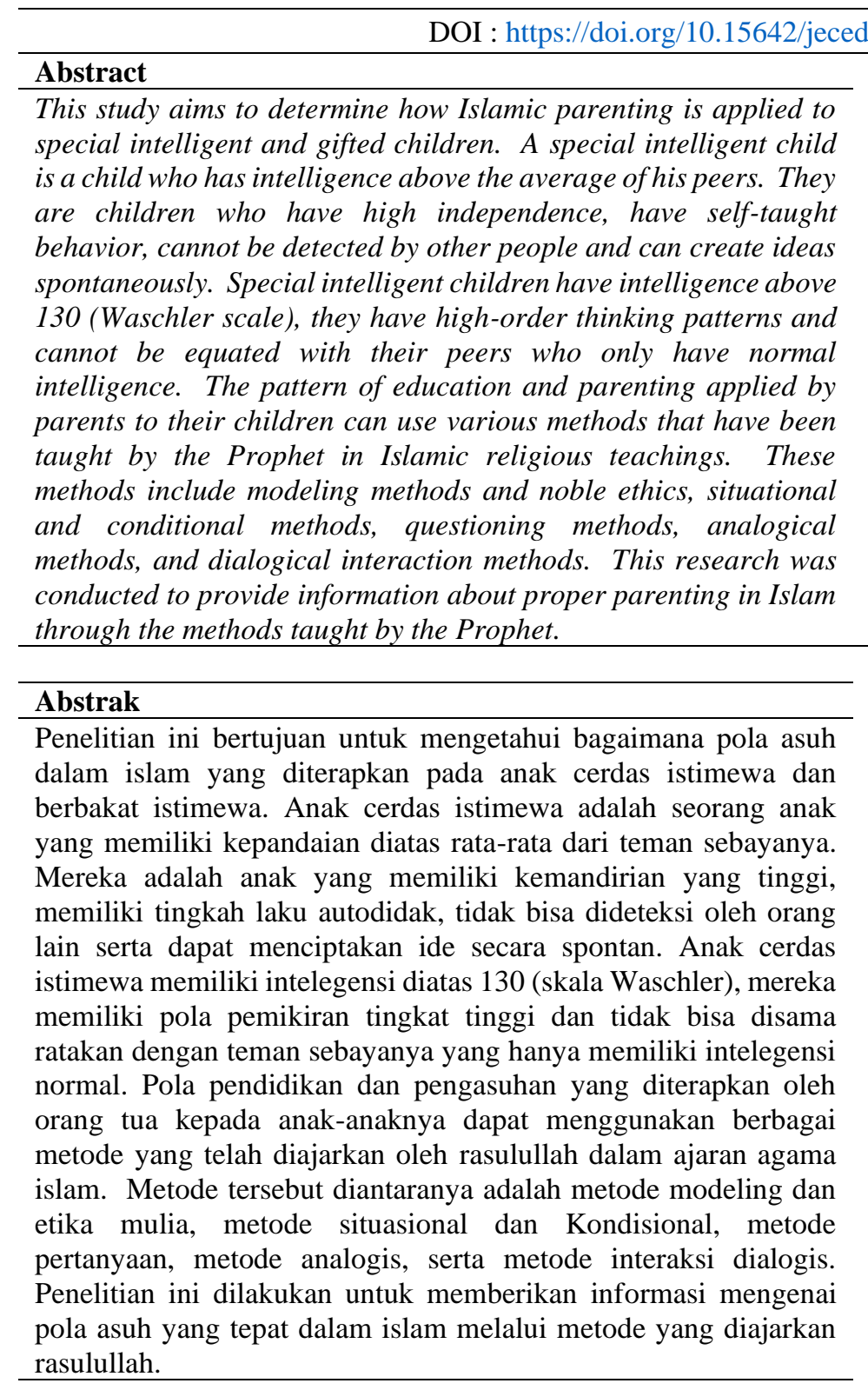

\section{Article Info}

Article history:

Received: April 15, 2021

Approved: June 29, 2021

Published online: April 30, 2021

\section{Keywords:}

Child,

Parenting,

\section{Gifted}

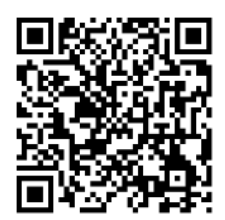

\begin{tabular}{l}
\hline Informasi Artikel \\
\hline Riwayat Artikel \\
Diterima: 15042021 \\
Disetujui: 29062021 \\
Publikasi online: 01062021 \\
\hline
\end{tabular}

\section{Kata kunci:}

Anak,

Pola Asuh,

Cerdas Istimewa

\section{Informasi Artikel} memiliki pola pemikiran tingkat tinggi dan tidak bisa disama normal. Pola pentiken dan pengsuhen yang diterapka oleh orang tua kepada anak-anaknya dapat menggunakan berbagai metode yang telah diajarkan oleh rasulullah dalam ajaran agama islam. Metode tersebut diantaranya adalah metode modeling dan etika mulia, metode situasional dan Kondisional, metode pertanyaan, metode analogis, serta metode interaksi dialogis. Penelitian ini dilakukan untuk memberikan informasi mengenai pola asuh
rasulullah 


\section{PENDAHULUAN}

Pendidikan adalah hal terpenting dalam kehidupan setiap orang. Hal ini dimulai sejak dari dalam kandungan. Dalam tahapan atau fase kehidupan, pendidikan merupakan fase terpenting. Apalagi, pada saat anak berada di usia dini dimana usia tersebut adalah usia yang sangat mudah dibentuk dan sangat membutuhkan pola pengasuhaan terbain dan pendidikan terbaik dari orang tuanya. Menurut Abu (2009: p.29) "Anak adalah manusia kecil yang memiliki potensi dan kemampuan". Anak bukan manusia dewasa yang tercipta dalam bentuk kecil karena mereka harus melalui pendidikan dan pembelajaran yang sangat panjang untuk terus belajar dan menemukan jati dirinya sebagai orang dewasa. Anak Usia Dini melewati 4 tahapan. Pertama yaitu usia satu tahun atau biasanya disebut masa bayi. Tahapan kedua adalah masa batita atau bawah tiga tahun atau anak berusia satu sampai tiga tahun. Tahapan yang ketiga yaitu anak berusia tiga sampai lima tahun atau disebut sebagai masa pra sekolah. Tahap keempat adalah masa sekolah dasar. Usia pada tahap ini adalah enam sampai delapan tahun (John, 2004: p.35). Jadi, dapat ditarik kesimpulan bahwa anak usia dini adalah anak yang berada pada usia 0 sampai dengan 8 tahun.

Tanda-tanda kecerdasan pada anak dapat dilihat sejak anak berada pada saat usia dini. Anak Cerdas Istimewa berarti anak yang memiliki kecerdasan seorang anak yang berada di atas rata-rata teman sebayanya atau memiliki intelegensi tinggi yang mencerminkan kecerdasan luar biasa (Widyorini, 2015, p.15). Masing-masing anak pastinya memiliki kecerdasan yang berbeda-beda. Ada pula anak yang memiliki kecerdasan istimewa yang mana biasanaya anak tersebut sering mengalami kesulitan dalam berteman dengan sebayanya sampai dengan kesulitan dalam menerima pendidikan. Iq pada anak cerdas istimewa biasanya diatas nilai 130, yang mana mereka seringkali memperlihatkan tingkahlaku negatif terhadap pendidikan yang mereka terima dan mereka menganggap pola pikirnya lebih maju dibandingkan teman-teman sebayanya. Kebosanan akans ering terjadi pada anak cerdas istimewa karena biasanya ketika dalam belajar ilmu yang diajarkan tidak sama atau tidak sesuai dengan tingkatan pola pikirnya.

Oleh karena itu, anak cerdas istimewa biasanya lebih suka menyendiri, hioeraktif dalam kelas, tidak mau untuk mengerjakan tugas sehingga membuat orang lain beranggapan bahwa anak tersebut kurang cerdas, ada juga yang menyebut sebagai anak nakal dan sebutan lain yang tidak tepat. Anak cerdas istimewa tersebut dapat mengalami banyak kesulitas karena dalam perkembangannya terdapat perbedaan dalam tingkat aspek yang ada di dalam dirinya. Contohnya adalah anak yang pintar dalam matematika tetapi mengalami keterlambatan dalam berbicara. Hal ini terjadi karena anak tersebut senang dalam belajar matematika dan lebih banyak mengembangkan kemampuannya untuk logika sehingga kemampuan dalam berbicaranya kurang terasah sehingga menyebabkan keterlambatan dalam berbicara.

Tertuang dalam Al Qur'an bahwa dalam islam rasulullah telah memberikan banyak tauladan dalam mendidik anak dan bahkan untuk seluruh manusia, berikut ini artinya :

"Dialah Allah yang telah mengutus, mengirimkan kepada kaum ummi (buta huruf) seorang rasuk dari golongan mereka sendiri, yang telah membacakan ayat-ayatn Nya kepada mereka, (berjuang mensucikan mereka, serta mengajarkan kitab dan hikmah (Assunnah) Sesungguhnya mereka sebelum diutusnya Muhammad benar-benar dalam kesesatan yang nyata" [QS. Al-Jumuah:2].

Anak cerdas istimewa yang memiliki IQ di atas rata-rata membutuhkan pengasuhan dan pendidikan khusus yang bisa menangani kebutuhan mereka dalam mengembangkan kemampuan mereka dan mereka tetap bisa bersosialisasi dengan teman sebayanya 
(Wilcox, 2013, p.44). Oleh karena itu, pada penelitian ini peneliti ingin mengetahui apakah anak cerdas istimewa dan bagaimana pola pengasuhan pada anak cerdas istimewa dalam islam.

\section{METODE}

Penelitian ini menggunakan metode penelitian studi pustaka. Studi pustaka adalah sebuah metode yang dilakukan oleh peneliti dengan mengumpulka informasi-informasi yang relevan dengan topik atau permasalahan yang sedang diteliti. Dalam hal ini, berbagai informasi-informasi tersebut diperoleh dari buku-buku ilmiah, laporan penelitian, dan sumber tertulis baik cetak maupun elektronik.

Penelitian ini bertujuan untuk mencari informasi yang relevan dengan masalah yang diteliti, serta mencari landasan teori yang digunakan sebagai pedoman untuk pendekatan solusi masalah pemikiran. Setelah peneliti mendapatkan sumber-sumber pustaka yang akan digunakan, peneliti melakukan identifikasi terhadap masalah dan mencocokkan sumber yang relevan dengan masalah yang diangkat. Identifikasi ini dilakukan agar mendapatkan solusi serta penjelasan terhadap masalah yang sedang diangkat dan diteliti.

\section{HASIL DAN PEMBAHASAN}

Anak cerdas istimewa merupakan seorang anak yang sangat mandiri, memiliki tingkahlaku yang autodidak, mereka juga dapat dengan spontan menciptakan ide serta sulit untuk menerima perintah (Sangkanparan, 2012' pp 11-12). Karakteristik yang dimiliki anak tersebutlah yang menyebabkan mereka para ana cerdas istimewa tidak bisa untuk diperlakukan sam seperti teman-teman sebayanya yang memiliki kecerdasan normal. Mereka akan melawan saat di perintah melakukan sesuatu yang tidak sesuai dengan pola piker dan kemauan mereka.

Menurut Wilcox (2013, p.189), Inteligensi adalah kapasitas belajar berdasarkan pengalaman dan penyesuaian diri seseorang dengan lingkungannya. Skala inteligensi dari Wechsler adalah tes individual bagi anak-anak dan orang dewasa nilai 130 ke atas dianggap cerdas sedangkan dibawah 70 dianggap kurang cerdas. Anak-anak yang memiliki kelebihan yaitu cerdas istimewa, mereka memiliki nilai IQ diatas 130, sehingga dengan kecerdsan yang luar biasa tersebut sangat disayangkan dan sangat memprihatinkan apabila kecerdasannya tersebut harus terluka hanya dikarenakan pola pengasuhan yang diterapkan oleh orang tuanya adalah pola pengasuhan yang kurang tepat. Anak cerdas istimewa memiliki manfaat yang sangat besar bagi dirinya sendiri maupun bagi masyarakat apabila potensi kecerdasannya dan kemampuannya yang tinggi tersebut dijaga, dikembangkan, dan digunakan dengan baik dan benar. Orang tua, guru dan lingkungan sekitar anak cerdas istimewa memiliki peran pending untuk mendukung kemampuannya tersebut agar potensi yang mereka miliki dapat dikembangkan dan diwujudkan dalam bentuk prestasi yang sesuai dengan potensinya yang istimewa tersebut (Gunawan, 2012, p.61).

Anak cerdas istimewa disebut sebagai anak yang memiliki IQ tinggi sejak lahir atau bawaan lahir, tetapi anak cerdas istimewa tersebut dapat berkembang dengan baik jika stimulasi yang diberikan jga baik dan tepat. ketika Kebutuhannya akan nutrisi dipenuhi dengan pemberian makanan yang bergizi. Selain itu, kebutuhan terhadap kasih sayang dan rasa aman dari oraang sekitarnya juga sangat bermanfaat untuknya., serta kebutuhan perkembangan kecerdasannya dilakukan dengan rangsangan stimulasi belajar dalam pendidikan yang baik. 
Menurut Adinugroho (2007), Perkembangan yang overexcibility (superstimulatibilities) berbagai aspek tumbuh kembang individu cerdas istimewa meliputi aspek psikomotor, sensual, intelektual, imajinasi, dan emosi. Seorang anak cerdas istimewa dapat berkembang dalam kondisi ekstrim sensitif ketika berada dalam beberapa aspek, hal ini merupakan definisi dari Overexcibilit.y

1. Psikomotor

Kepekaan yang sangat tajam dan ekstrim dalam psikomotor, dalam bergerak dan memiliki banyak energi merupakan ciri dari anak cerdas istimewa. Sehingga dalam hal ini mereka yang memiliki kecerdasan istimewa pasti banyak bicara serta memerlukan waktu tidur yang lebih sedikit dari waktu anak-anak normal. Selain itu, mereka memiliki rasa ingin tahu yang sangat besar dibandingkan dengan teman sebayanya.

2. Sensual

Anak yang memiliki kecerdasan istimewa lebih menyukai hal-hal yang menantang sensornya, hiperaktif, sensitif terhadap cahaya-cahaya, dan baju yang basah. Anak yang memiliki kecerdasan istimewa memiliki kesadaran yang kuat terhadap kecantikan. Bahkan mereka juga gampang untuk menangis jika mendengarkam lagu atau musik sedih atau sendu. Anak cerdas istimewa juga tidak suka dengan sesuatu yang bertekstur cair atau lembek seperti cat air, maupun plastisin. Karena indra yang dimiliki oleh anak cerdas isttimewa ini adalah sangat sensitif

3. Intelektual

Bermain puzzle merupakan sesuatu hal yang disukai oleh anak cerdas istimewa karena hal ini dapat melatih otaknya dan merangsang otak. Kemampuan membaca dan berhitung dari anak cerdas istimewa biasanya bisa melampaui teman-teman sebayanya. Anak cerdas istimewa ini biasanya belaar sendiri dengan benda atau hal yang ada disekitarnya.

4. Imajinasi

Imajnasi yang tinggi dimiliki oleh anak cerdas istimewa. Mereka selalu berfikir visual dan banyak menggunakan bahasa metafora. Selain itu, mereka dengan kecerdasan istimewanya juga membuat sering melamun, kuat ingatannya dan mereka sangat menyukai dongeng.

5. Emosi

Anak Cerdas Istimewa dengan kepekaan emosi yang ekstrim. Perkembangan emosinya luas, dalam, sangat empati dan mudah merasa iba. Anak cerdas istimewa sangat sensitif dan mereka mudah membuat lelucon atau humor, tetapi kelemahannya jika orang lain membalas humornya maka ia akan mudah tersinggung dan tersakiti.

Pola asuh menurut Islam adalah suatu kesatuan yang utuh dari sikap dan perlakuan orang tua kepada anak dalam mendidik, mengasuh, membiasakan, dan membimbing anak secara optimal berdasarkan pada Al Quran dan Sunnah dari Rasulullah SAW (Drajat, 2006, p.80). Hal ini berarti bahwa mebicarakan pola pengasuhan jika menurut Islam sangatlah berbeda dengan pandangan dan pendapat para ahli yang cenderung memaknai pola asuh hanya sebagai suatu gaya kepemimpian orang tua terhadap anak-anaknya.

Pola asuh anak dalam Islam meliputi segala bentuk perlakuan pada anak dalam membantu tumbuh kembang anak, temasuk keteladanan orang tua. Dalam Al-Qur'an dan Hadist sudah digambarkan secara menyeluruh tujuan, pendekatan dan metoda pembentukan perilaku anak, namun dalam aplikasinya dapat diperkaya dengan hasil temuan penelitian yang berbasis empirik (Drajat, 2006, p.81). Melalui pola pengasuhan 
yang diterapkan oleh orang tua untuk menyiapkan anak-anaknya bukan hanya untuk dapat di terima oleh semua kalangan masyarakat, tetapi juga menjadi hamba Allah yang taat dan patuh terhadapa perintahnya sehingga mereka selamat di dunia dan akhiratnya.

Rasulullah sebagai Rasul dan Nabi terakhir telah memberikan tauladan dan pengajaran pada semua umat manusia. Tauladan ini dapat diterapkan oleh semua umat manusia. Menurut Drajat (2006, pp.81-83) penerapan tersebut khususnya untuk anakanak cerdas istimewa, diantaranya adalah sebagai berikut :

1. Metode modeling dan etika mulia

Guru dan orang tua sebagai Role Model bagi anak. Jika dilihat, anak-anak terkesan tidak peduli dan sangat menikmati dunianya sendiri tetapi mereka sebenarnya melihat dan memperhatikan oarang yang ada disekitarnya. Ketika anak menemukan sebuah perbedaan tentang apa yang mereka dapat disetiap perlakuannya, mereka akan melakukan protes untuk mendapatkan persamaan atas hak yang harus mereka dapat. Oleh karena itu, sebagai seorang pendidik harus dapat memberikan model atau contoh kepada para peserta didik tidak terkecuali kepada anak cerdas istimewa juga.

2. Metode situasional dan Kondisional

Anak Cerdas Istimewa memiliki kondisi yang berbeda dengan teman sebayanya yang normal. Di satu sisi dia mengalami kemajuan yang sangat cepat namun di sisi lain ada perkembangannya yang terhambat. Oleh karena itu sebagai orang tua maupun pendidik harus memahami situasi dan kondisi anak maupun peserta didik yang mana mereka adalah anak cerdas istimewa.

3. Metode pertanyaan

Orang tua maupun pendidik dapat menggunakan metode pertanyaan untuk memancing agar anak berpikir logis. Anak-anak cerdas istimewa biasanya akan terasah dengan segudang pemikiran yang banyak sekali pertanyaannya. Orang tua atau pendidik juga bisa mengecek pemahaman anak agar tidak melenceng dari yang seharusnya.

4. Metode analogis

Anak Cerdas Istimewa mampu berpikir kritis. Orang tua atau pendidik bisa mengasah kemampuan analogi yang dimiliki dan mengarahkan untuk berpikir lurus agar tidak mudah dibohongi orang lain. Anak Cerdas Istimewa yang memiliki rasa takut pada kegelapan, memiliki bayangan yang menakutkan mengenai kegelapan. Bagi anak-anak tersebut kegelapan yang mewakili misteri tersebut sangat luar biasa dan dimana rasa takut itu tinggal.

5. Metode interaksi-dialogis

Metode Interaktif-Dialogis (Tanya Jawab) Anak Cerdas Istimewa yang memiliki kelebihan di bidang bahasa/linguistik akan sangat cocok dengan pembelajaran ini. Disamping kesukaannya akan berbicara, dia juga memiliki pola pikir yang kritis. Oleh sebab itu, Anak Cerdas Istimewa sangat menyukai metode ini..

\section{SIMPULAN}

Anak Cerdas Istimewa disebut sebagai anak yang sangat mandiri dan berpikir dengan spontan, bertingkah secara autodidak dan mereka senang menghasilkan ide-ide secara spontan juga. Dia sulit untuk menerima perintah. Anak yang memiliki kecerdasan istimewa memiliki nilai IQ diatas 130. Sehingga denga kecerdasan yang mereka miliki tersebut pola asuh yang diterapkan harus sesuai dan tepat. Jika kurang tepat maka sangat disayangkan sekali akan kecerdasannya. Anak cerdas istimewa ini memiliki manfaat yang 
besar bagi dirinya sendiri maupun bagi oarang disekitarnya. Ada berbagai macam metode yang digunakan dalam pola pengasuhan anak cerdas istimewa. Metode tersebut telah dibawa dan diajarkan oleh Rasulullah sebagai rasul dan nabi terakhir umat islam. Metodemetode itu diantaranya adalah metode modeling dan etika mulia, metode situasional dan Kondisional, metode pertanyaan, metode analogis, serta metode interaksi dialogis. Metode-metode tersebut digunakan dalam mengasuh dan mendidik anak cerdas istimewa dengan melihat serta disesuaikan dengan situasi dan kondisi pada anak-anak.

\section{DAFTAR PUSTAKA}

Adinugroho \& Horstman. 2007. Model Pendidikan Gifted dan Talented. Makalah

Alfianita, I. C., \& Gunansyah, G. (2018). Kompetensi Pedagogik Guru Untuk Siswa Cerdas Istimewa (Gifted) Program Kelas Akselerasi Di MI Maarif NU Pucang Sidoarjo. Jurnal Penelitian Pendidikan Guru Sekolah Dasar, 6(8).

Badiah, L. I., Jauhari, M. N., \& Sambira, S. (2020). Peningkatan Keterampilan Guru Paud Dalam Menyusun Program Pembelajaran Individual Anak Berkebutuhan Khusus Di PAUD Permata Bunda. SPEED Journal: Journal of Special Education, 3(2), 95100.

Dradjat, Zakiah.2006. Ilmu Pendidikan Dalam Islam. Jakarta: PT Bumi Aksara.

Eva, N. (2018). Determinan Prestasi Akademik Ilmu Pengetahuan Alam (IPA) Siswa Cerdas Istimewa dengan Self-Regulated Learning sebagai Mediator (Doctoral dissertation, UNIVERSITAS AIRLANGGA).

Ghuddah, Abdul Fattah Abu. 2009. 40 Metode Pendidikan dan Pengajaran

Rasulullah saw. Bandung: Irsyad Baitus Salam.

Gottman, John. 2004. Mengasuh Anak dengan Hati. Yogyakarta: Prisma Media

Gunawan, Adi. 2012. Genius Learning Strategy; Petunjuk Praktis untuk

menerapkan Accelerated Learning. Jakarta: PT Gramedia Pustaka Utama.

Maria van Tiel, Julia dan Endang Widyorini. 2015. Deteksi dan Penanganan Anak

Cerdas Istimewa (Anak Gifted) melalui Pola Alamiah Tumbuh

Kembangnya. Jakarta : Prenadamedia Group

Sangkanparan, Hartono.2012. Mencetak Superman Masa Depan. Jakarta :

Visimedia Sari, Wiwik Nurfita. Perkembangan Sosial Anak Gifted Talent Dalam Bersosialisasi Dengan Teman Sebaya. Diss. University of Muhammadiyah Malang, 2019.

Wilcox, Kumalahadi. 2013. Psikologi Kepribadian; Analisis Seluk beluk

Kepribadian Manusia. Yogyakarta: IRCiSoD 